\title{
Assessment of Guidance Needs of Junior High School Teachers in the Cape Coast Metropolis - Ghana
}

\author{
Ampofo-Agyare, Mary Owusua \\ University Junior High School, University of Cape Coast, Ghana
}

\begin{abstract}
This study assessed the counselling needs of JHS teachers in the Cape Coast Metropolis with the view to ranking the guidance needs of teachers which have the potential of adversely affecting quality teaching and learning process. The survey consisted of 204 subjects drawn from selected schools from all the 6 circuits in the Cape Coast metropolis. The research instrument used was a questionnaire. One-way Analysis of Variance (ANOVA) was used to analyze the hypotheses at 0.05 level of significance. It was also found that generally, there was no statistically significant gender difference with regards to the guidance needs involved in the study.

Based on the findings, it was recommended that the various Ghana Education Service guidance personnel assigned to all the District Education Offices should put in place right measures to identify the needs of teachers and offer them the needed guidance assistance where applicable. It is also recommended that the Ghana Education Service in collaboration with the Ministry of Education should provide permanent and professional guidance personnel to all the basic schools to assist the various district guidance personnel in attending to the guidance needs of teachers.
\end{abstract}

Keywords: Guidance and counseling, Teachers, Ghana Education Service, Cape Coast

\section{INTRODUCTION}

Teachers like other workers are often faced with personal-social, educational and career issues that may adversely impact on their performance. Compounded by several challenges at the workplace which include government restructuring programmes, among others, there is the need to provide counselling services to teachers. For productivity to be enhanced ,there should be counselling service, thereby justifying the high wage bills incurred by various employing agencies, problems that may confront teachers that will limit the scope of their functioning would have to be identified and tackled (Downing, 1968). The Ghana Education Service has formalized and integrated Guidance and Counselling services in the education system. However over the years these initiatives have focused more on students while putting less emphasis on the teachers' psychosocial needs. It is a common knowledge that in Ghana, the various Ghana Education Service (GES) guidance and counselling co-ordinators in the various educational directorates only visit schools to acquaint themselves with the guidance and counselling needs of pupils and students and not the teachers. It appears they are not interested in finding out the causes of low output of work of teachers, but are only interested in taking disciplinary actions against those teachers.

For every country to develop, premium has to be placed on the importance of developing and preserving its human resource base. As a helping relationship, guidance is designed virtually for all persons. The nature and intensity of the assistance varies from person to person and from one group to another, depending on the peculiar needs of such individuals or groups. One of such groups with peculiar needs for guidance, but whose needs have not yet received much attention from appropriate authorities is the Ghanaian teacher.

The central research problem of the study is that Ghanaian teachers like other employees are often faced with personal-social, educational and career issues that may adversely impact their work output. However, guidance needs of teachers have received inadequate attention by the stakeholders of education such as Ghana government and Ghana Education Service (G. E. S.) over the years. It is on record that trained guidance and counselling teachers are posted to schools to function as guidance coordinators because the authorities believe that pupils and students are confronted with problems that need guidance service. The focus has always being on addressing the guidance needs of pupils and students such as peer influence, career, school and programme choice. The 1976 Ghana Education 
Service policy on the introduction of guidance and counseling programmes in all schools also focused on the students and not teachers (Danquah, 1987).

However, for productivity of teachers to be enhanced, various problems that confront them and have the potential to limit the quality of their performance such as educational, career, and personal-social needs would have to be identified and addressed since teachers are the key implementers of government's educational policies. This also means that problems and challenges faced by teachers can have adverse effect on teaching and learning. Therefore, this study intends to investigate the most prevalent educational, career and personal-social guidance needs of junior high school teachers in Cape Coast metropolis for efficient service delivery.

\section{HYPOTHESES}

The study was guided by testing the following hypotheses:

1. There is no significant difference between the personal-social guidance needs of male and female JHS teachers in Cape Coast metropolis.

2. There is no significant difference between the educational guidance needs of male and female JHS teachers in Cape Coast metropolis.

3. There is no significant difference between the career guidance needs of male and female JHS teachers in Cape Coast metropolis.

\section{THEORETICAL FRAMEWORK}

Alderfer's ERG theory was used for the study. To begin his theory, Alderfer collapses Maslow's five levels of needs into three categories. Alderfer (1972) developed a comparable hierarchy with his ERG (Existence, Relatedness, and Growth) theory. The theory says that as you start satisfying higher needs, they become more intense. For example, the power you get the more you want power, like an addiction.In Alderfer's model, sex does not need to be in the bottom category as it is in Maslow's model, since it is not crucial to (the individual's) existence.

Another difference between Maslow and Alderfer is that Alderfer considered that people could move around the hierarchy meeting their needs. People do not start at the bottom and work their way up. People might be meeting their relatedness or social needs whilst tired or hungry. They might meet their need for personal growth by studying alone, even though they feel lonely. Alderfer also argued that people could go backwards in meeting needs. If people are frustrated in meeting their higher order needs - no recognition of their work, feeling unvalued, they may start meeting lower order needs even though these are already satisfied. People may eat too much, drink too much, concentrate on making money to compensate themselves for not achieving the higher order needs. However, both theories are similar because they all see needs as the motivating force behind behaviour.

Based on the Alderfer's theory of needs, Maslow recognized that not all personalities followed his proposed hierarchy. While a variety of personality dimensions might be considered as related to motivational needs, one of the most often cited is that of introversion and extroversion. Reorganizing Maslow's hierarchy based on the work of Alderfer and considering the introversion/extraversion dimension of personality results in three levels, each with an introverted and extroverted component. This organization suggests there may be two aspects of each level that differentiate how people relate to each set of needs. Different personalities might relate more to one dimension than the other. For example, an introvert at the level of Other/Relatedness might be more concerned with his or her own perceptions of being included in a group, whereas an extrovert at that same level would pay more attention to how others value that membership.

This approach proposes that unsatisfied needs motivate behaviour, and that as lower level needs are satisfied, they become less important. Higher level needs, though, become more important as they are satisfied, and if these needs are not met, a person may move down the hierarchy, which Alderfer calls the frustration-regression principle. What he means by this term is that an already satisfied lower level need can become reactivated and influence behaviour when a higher level need cannot be satisfied. As a result, employers should provide opportunities for workers to capitalize on the importance of higher level needs. Similarly, according to McClelland (1957) cited in Norwood (1999) also propounded a motivation theory known as "acquired needs theory". This theory recognizes the fact that everyone prioritizes needs differently. 


\section{SAMPLE Size AND SAMPLing TechniQue}

The major focus of this part was to determine the specific population surveyed, to decide on an appropriate sample, and to determine the criteria that was used to select the sample size. Cohen, Manion, and Morrison (2004) indicated that researchers must obtain a minimum sample size that will accurately represent the target population. In this study a sample size of 204 was used based on the mathematical table of Krejcie and Morgan (1970), which is in a form of random sampling technique. According to the table of Krejcie and Morgan, a population size of 440, for instance, should have a sample size of 205 . This implies that in this study which involves a population of 435 , the sample size of 204 is appropriate.

\section{INSTRUMENT}

A self- developed questionnaire by the researcher was used to gather relevant data for the study. The researcher considered the use of questionnaire appropriate to collect the data for the study since the participants could read and comprehend, even though the researcher was not oblivious of its drawbacks.

\section{TEST OF HYPOTHESES}

There is no significant difference between the personal-social guidance needs of male and female JHS teachers in Cape Coast metropolis.

In the study, personal-social guidance needs covers financial guidance needs, stress guidance needs and marital guidance needs of the teachers. Table 1 presents the summary of the results.

Table1. Combined ANOVA Statistics on Personal-Social Guidance Needs of Participants

\begin{tabular}{|l|l|l|l|l|l|l|}
\hline Variable & Groups & $\begin{array}{l}\text { Sum } \\
\text { of Squares }\end{array}$ & df & $\begin{array}{l}\text { Mean } \\
\text { Square }\end{array}$ & F & Sig. \\
\hline \multirow{2}{*}{$\begin{array}{l}\text { Financial Guidance } \\
\text { Needs of Teachers }\end{array}$} & Between Groups & 46.123 & 1 & 46.123 & 338.309 & .000 \\
\cline { 2 - 7 } & Within Groups & 27.539 & 204 & .136 & & \\
\hline \multirow{2}{*}{$\begin{array}{l}\text { Stress Guidance Needs of } \\
\text { Teachers }\end{array}$} & Between Groups & 40.593 & 1 & 40.593 & 359.116 & .000 \\
\cline { 2 - 7 } & Within Groups & 22.833 & 204 & .113 & & \\
\hline \multirow{2}{*}{ Marital Guidance Needs } & Between Groups & 31.373 & 1 & 31.373 & 272.973 & .000 \\
\cline { 2 - 7 } & Within Groups & 23.216 & 204 & .115 & & \\
\hline
\end{tabular}

Source: Field Data, $2012 \quad d f=1, \quad \alpha=0.05$

The results of the pooled ANOVA statistics of the personal-social guidance need variables in Table 1 indicate that there is statistically significant gender difference in respect of marital, stress and financial guidance needs. This was due to the fact that each of the variables scored significant value of 0.000 which is far below the alpha value of 0.05 .

\section{Hypothesis Two}

There is no significant difference between the educational guidance needs of male and female JHS teachers in Cape Coast Metropolis.

The objective was to test whether the null hypothesis will be rejected or not. Table 28 presents the summary of the findings.

Table28. ANOVA Statistics of Gender Difference in Educational Guidance needs of Participants

\begin{tabular}{|c|c|c|c|c|c|c|}
\hline Educational Guidance Needs & Groups & $\begin{array}{l}\text { Sum } \\
\text { of Squares }\end{array}$ & df & $\begin{array}{l}\text { Mean } \\
\text { Square }\end{array}$ & $\mathrm{F}$ & Sig. \\
\hline \multirow{2}{*}{$\begin{array}{l}\text { I need help to know when to further my } \\
\text { education }\end{array}$} & Between & .397 & 1 & .397 & 3.459 & .064 \\
\hline & Within & 23.186 & 204 & .115 & & \\
\hline \multirow{2}{*}{$\begin{array}{l}\text { I need help to enable me choose educational } \\
\text { programme }\end{array}$} & Between & .314 & 1 & .314 & 1.408 & .237 \\
\hline & Within & 45.020 & 204 & .223 & & \\
\hline \multirow{2}{*}{$\begin{array}{l}\text { I need help to know the various job } \\
\text { opportunities available for every programme } \\
\text { of study }\end{array}$} & Between & .593 & 1 & .593 & 2.153 & .144 \\
\hline & Within & 55.657 & 204 & .276 & & \\
\hline \multirow{2}{*}{$\begin{array}{l}\text { I need help to know the requirement when } \\
\text { applying for a particular academic } \\
\text { programme }\end{array}$} & Between & .000 & 1 & .000 & .000 & .000 \\
\hline & Within & .000 & 204 & .000 & & \\
\hline
\end{tabular}




\begin{tabular}{|l|l|l|l|l|l|l|}
\hline \hline \multirow{2}{*}{$\begin{array}{l}\text { I need help to enable me have full } \\
\text { concentration when studying }\end{array}$} & Between & .706 & 1 & .706 & .784 & .377 \\
\cline { 2 - 7 } & Within & 181.922 & 204 & .901 & & \\
\hline \multirow{2}{*}{$\begin{array}{l}\text { I need help to enable me know much about } \\
\text { study leave issues }\end{array}$} & Between & .176 & 1 & .176 & .553 & .458 \\
\cline { 2 - 7 } & Within & 64.471 & 204 & .319 & & \\
\hline \multirow{2}{*}{$\begin{array}{l}\text { I need help in getting information on } \\
\text { available scholarships in connection with my }\end{array}$} & Between & 1.417 & 1 & 1.417 & 1.985 & .160 \\
\cline { 2 - 7 } & Within & 144.167 & 204 & .714 & & \\
\hline $\begin{array}{l}\text { I need help in getting information about the } \\
\text { right institution to choose for further studies }\end{array}$ & Between & .593 & 1 & .593 & 2.589 & .109 \\
\cline { 2 - 7 } & Within & 46.284 & 204 & .229 & & \\
\hline
\end{tabular}

Source: Field Data, $2012 \quad d f=1, \quad \alpha=0.05$

As shown in Table 2, only the item 'I need help to know the requirement when applying for a particular academic programme' scored a significant .000 which is less than the alpha level of 0.05 implying that there is a statistically significant gender difference with regards to the item. All the remaining items recorded significant values more than the alpha level $(0.05)$ indicating that there is no statistically significant gender difference with regards to those items in connection with the educational guidance needs of teachers in the Cape Coast metropolis.

\section{Hypothesis Three}

There is no significant difference between Career Guidance needs of male and female JHS Teachers in Cape Coast metropolis.

It comprises interpersonal, retirement and job changing guidance needs of teachers. Career guidance refers to services intended to assist people, of any age and at any point throughout their lives to make educational, training and occupational choices and to manage their careers. Career guidance helps people to reflect on their ambitions, interests, qualifications and abilities. It helps them to understand the labour market and education systems, and to relate this to what they know about themselves. Comprehensive career guidance tries to teach people to plan and make decisions about work and learning. Career guidance makes information about the labour market and about educational opportunities more accessible by organizing it, systematizing it, and making it available when and where people need it.

Combined ANOVA statistics was computed to compare the differences among the various career guidance variables in terms of gender. Table 3 presents the summary of the finding of the pooled analysis.

As shown in Table 3, the result of the pool ANOVA statistics of career guidance needs variables and gender indicated significant values above the alpha value of $0.05(\mathrm{p}>0.05)$ for all the 3 variables investigated. This implies that there is no significant gender difference with regards to career guidance needs of JHS teachers in the Cape Coast Metropolis.

Table33. Combined ANOVA Statistics on Career Guidance Needs of Participants

\begin{tabular}{|l|l|l|l|l|l|l|}
\hline Variable & Groups & Sum of Squares & Df & Mean Square & F & Sig. \\
\hline Retirement & Guidance Needs & 0.292 & 1 & 0.292 & 0.970 & 0.476 \\
\cline { 2 - 7 } & Within Groups & 65.864 & 204 & 0.326 & & \\
\hline $\begin{array}{l}\text { Interpersonal } \\
\text { Guidance Needs }\end{array}$ & Between Groups & 0.461 & 1 & 0.382 & 1.227 & 0.373 \\
\cline { 2 - 8 } & Within Groups & 64.580 & 204 & 0.320 & & \\
\hline $\begin{array}{l}\text { Job Changing } \\
\text { Guidance Needs }\end{array}$ & Between Groups & 0.586 & 1 & 2.17 & 3.799 & 0.148 \\
\cline { 2 - 8 } & Within Groups & 48.098 & 204 & & & \\
\hline
\end{tabular}

Source: Field Data, 2012

$$
d f=1, \quad \alpha=0.05
$$

\section{DisCUSSION OF RESULTS}

The statistical analysis of results of this study showed that all the personal-social guidance needs variables (financial, stress and marital) investigated are prevalent among the Junior High school teachers in the Cape Coast metropolis.

ANOVA statistics on stress guidance needs and gender showed that out of 6 items on stress needs, 2 items, 'I need help on how to be informed about causes of workplace stress' and 'I need help on how to improve my physical well-being' scored significant values 0.000 and 0.036 respectively which were above the alpha level of 0.05 implying the existence of statistically significant gender difference 
with regards to those items. This result is in line with the finding by Adepoju (2001) which indicated that women are more likely to report physical and emotional symptoms of stress than men. Viner (1999) also indicated that there is statistically significant difference between genders for stress level of physical environment, social environment and self-interpretation.However, with regards to the remaining stress needs items, the result showed no statistically significant gender difference.

Similarly, finding on marital guidance needs and gender showed that only 'I need help on how to get along with an extrovert spouse' which scored a significant value less than 0.5 indicating a statistically significant gender difference. All the other items on marital needs did not reject the null hypothesis. Regarding financial guidance needs and gender, the item 'I need help to enable me invest my money prudently' scored a significant value less $(0.001)$ less than 0.05 indicating a statistically significant gender difference which rejected the null hypothesis. However, all the other items on financial guidance needs showed no statistical gender difference.

Result for combined ANOVA statistics for stress, marital and financial guidance needs indicated that there is a statistically significant gender difference with regards to these personal-social variables as all of them scored significant value of 0.000 which is less than 0.05 .

The analysis of variance statistics of educational guidance needs of teachers in respect of gender indicated that there is no statistically significant gender difference in 7 out of the 8 items involved in the analysis. This result of the individual educational guidance items was confirmed by the pooled ANOVA statistics on teachers' educational guidance needs and gender.

ANOVA statistics on career guidance needs also revealed that concerning interpersonal needs of teachers at workplace 3 items out of the 6 items showed a statistically gender difference. These were 'I need help to know the likes and dislikes of my colleagues (0.006)', 'I need help to know how to interact with my colleagues $(0.011)$ and 'I need help to know how to interact with my superior at work with significant value of 0.037 . The remaining 3 items indicated no significance gender difference. Referring to Table 31, it was shown that all the items on retirement guidance needs indicated no statistically significant gender difference as all of the items scored significant values higher than 0.05. It was also clear from the finding that there is no gender difference when it comes to job changing guidance needs of teachers.

However, comparisons among the variables of career guidance needs of teachers with regards to gender difference indicated no statistically significant gender difference among all the variables (Retirement, Interpersonal and Job Changing needs) investigated as the combined results for all the variables showed a higher significant values than the alpha value of 0.05 .

\section{Conclusions}

Every human being and for that matter workers have one guidance need or the other. The main issue that has emerged from this study is consistent with findings on the importance of establishment of adequate guidance and counseling centres to meet the needs of teachers. The descriptive analyses revealed on all the needs (educational, career and personal-social) that generally JHS teachers in the Cape Coast metropolis lacked and required more guidance on all aspects of needs investigated.

It is for this reason that the provision of guidance services to teachers should be adequately supported by the Ministry of Education through the Ghana Education Service and Ghana National Association Teachers (GNAT) by providing a well resourced guidance offices with well-trained guidance and counselling coordinators in every educational directorate to identify and offer professional guidance services in meeting the needs of teachers. This will enable the basic school teachers to be more effective and productive. Furthermore, the country would also attain important global benchmarks, such as the Millennium Development Goal number two which targets access to and attainment of universal primary education by the year 2015 .

\section{RECOMMENDATIONS}

Based on the conclusions and findings that emerged from the study on guidance needs of teachers and the level at which these needs are met through guidance services, the following recommendations are made to improve upon the guidance needs of teachers:

1. The finding from the study has indicated that teachers have guidance needs (educational, career, personal - social) which may actually have adverse effects on the work output in schools. It is 
therefore recommended that various Ghana Education Service guidance co-ordinators assigned to all the district offices should put in place right measures to identify the needs of teachers and offer them the needed guidance assistance where necessary.

2. In view of the fact that almost all the guidance needs with regards to this study received a response of either inadequately met or not met at all, it is recommended that the Ghana Education Service should post professional guidance personnel to all basic school to see to the guidance needs of pupils and teachers as well.

3. It is also recommended that periodically, appraisal materials be made available by Ghana Education Service in all schools for teachers to know their capabilities and weaknesses. This will facilitate the easy identification of guidance needs of teachers so that it could be addressed.

4. The school guidance personnel should also create awareness of the existing guidance services by giving it a wider publicity to motivate teachers to patronize guidance services.

\section{REFERENCES}

Adepoju, T. L.(2001). Management of stress in education industry: Implications for educational managers. African Journal of Education, 9, 1, 25-35.

Alderfer, C. (1972). Existence, relatedness and growth. New York: Free Press.

Cohen, C., Manion, L., \& Morrison, K. (2004).Research methods in education. (5 $5^{\text {th }}$ ed.). London. Routlege publication Limited.

Danquah, S. A. (1987). School psychology in Ghana.Journal of School Psychology, 25, 247- 253.

Downing, L.W. (1968). Guidance and Counselling.An Introduction.New-York; McGraw Hill BookNew-York.

Krejcie, R. V., \& Morgan, D. W. (1970). Determining sample size for research activities.Educational and Psychological Measurement, 30, 607-610.

Norwood, G. (1999). Maslow's hierarchy of needs.The Truth Vectors (Part I). Retrieved July, 2011, from http://www.deepermind.com/20maslow.htm1

Viner, R., (1999), "Putting stress into life: Hans selye and making of stress theory", Journal ofSocial Studies and Science, 29, 3, 391-410. 